\title{
NEUROPHARMACOLOGICAL STUDY OF PHYLLANTHUS NIRURI IN SWISS ALBINO MICE
}

\author{
SARAVANAN P*, NAGARAJ P, MANI R \\ Department of Pharmacology, Coimbatore Medical College, Coimbatore, Tamil Nadu, India. Email: drsaranmd@gmail.com
}

Received: 23 November 2020, Revised and Accepted: 01 February 2021

\begin{abstract}
Objective: The objective of this study is to evaluate the neurological, behavioral, and autonomic changes of Phyllanthus niruri in Swiss albino mice using Irwin's method.

Methods: A total of 24 mice was divided into four groups of six each (3-male, 3-female in each group). Aqueous extract of $P$. niruri was prepared. Based on body weight aqueous extract was given to the mice by orally through gavage tube (Group I - $300 \mathrm{mg} / \mathrm{kg}$, Group II - 600 mg/kg, Group III - $900 \mathrm{mg} / \mathrm{kg}$, and Group IV - $1200 \mathrm{mg} / \mathrm{kg}$ ). Neuropharmacological profile is studied for each mice using Irwin's observational test, the mice were observed for $4 \mathrm{~h}$ after oral administration for various behavioral, neurological, and autonomic changes at $0,1,2,3,4 \mathrm{~h}$.
\end{abstract}

Results: P. niruri showed negligible actions at $300 \mathrm{mg} / \mathrm{kg}$ and $600 \mathrm{mg} / \mathrm{kg}$ body weight. At $900 \mathrm{mg} / \mathrm{kg}$ and $1200 \mathrm{mg} / \mathrm{kg}$ P. niruri showed certain behavioral and neuronal changes. P. niruri increased alertness, stereotypy, restlessness, irritability/aggressiveness in behavioral profile indicating that the drug is a CNS stimulant. Furthermore, it showed mild tremors in neurological profile indicating CNS excitation.

Conclusion: Aqueous extract of $P$. niruri at $900 \mathrm{mg} / \mathrm{kg}$ and $1200 \mathrm{mg} / \mathrm{kg}$ showed changes in behavioral profile, neurological profile, showing it as CNS stimulant properties. Since it is an observational study further research should be done to explore CNS stimulant properties in various in vivo studies.

Keywords: Phyllanthus niruri, Ayurvedic, Neuropharmacological profile, CNS stimulant.

(C) 2021 The Authors. Published by Innovare Academic Sciences Pvt Ltd. This is an open access article under the CC BY license (http://creativecommons.org/ licenses/by/4.0/) DOI: http://dx.doi.org/10.22159/ajpcr.2021v14i4.40343. Journal homepage: https://innovareacademics.in/journals/index.php/ajpcr

\section{INTRODUCTION}

The utilization of herbal plants to treat various human diseases is common in developing countries due to their easy access and low cost, compared with advanced Western medicine [1]. These herbal formulations were routinely used by humans throughout history, without any scientific evidence, but now are being used in practical clinical trials to find their optimum and beneficial and toxic therapeutic dose ranges [1]. This led to the development of numerous alkaloid drugs such as digitoxin in heart failure patients and anticancer drugs such as vincristine and vinblastine for various cancer [2].

Phyllanthus belongs to largest genus in the family Phyllanthaceae, with 11 sub-genus that comprise over 700 well-known species and are cosmopolitan in distribution, mainly in the tropics and subtropics. Plants of the genus Phyllanthus were utilized as herbal formulations for hundreds of years in many Southeast Asian countries, Brazil, India, and China. It is used in the Indian ayurvedic systems from the ancient times (more than 2000 years) [3].

Among the Phyllanthus species, Phyllanthus niruri is a small annual herb growing of height 30-60 cm. It is identified in Amazon rainforest and other tropical areas, including South East Asia, Southern India, and China. P. niruri L. has been extensively reported in traditional and folk medication systems such as Ayurveda and Siddha to treat various diseases including diabetes mellitus, jaundice, asthma, joint pain, immunomodulator, loss of appetite, constipation, injuries, as antimicrobial, conjunctivitis, gonorrheal diseases of males and females, inflammatory diseases, skin itching, kidney stones or failures, and urogenital disease [4-16]. Curative properties of P. niruri are due to the presence of polyphenols, include classes of chromones, coumarins, lignans, stilbenes, xanthones, and flavonoid [17-19].

Methanolic extract of $P$. niruri has been shown to mitigate the sensorimotor and cognitive deficit engendered by subacute chlorpyrifos exposure in rats. Studies on Phyllanthus species have been done in recent decades, but while most of the individual studies have focused in the composition of the constituents in various plant parts and the biological activities of plant extracts, hardly any study exists showing neuropharmacological profile using Irwin's method [20]. Hence, this study aims to evaluate the behavioral, neurological, and autonomic changes of P. niruri in Swiss albino mice using Irwin's test [21].

Objective

Evaluate neuropharmacological profile of P. niruri in Swiss albino mice using Irwin's method.

\section{MATERIALS AND METHODS}

The study was initiated after getting approval from the Institutional Animal Ethical Committee (IAEC) of Coimbatore Medical College. Proposal number is CMCH/PH/007/2019 on 29.4.2019. 24 Swiss Albino mice of both sexes, weighing 25-30 g were bought from authorized breeder. The animals were kept in central animal house, Coimbatore medical college for 1 week to acclimatization as per CPCSEA guidelines. Animals were maintained in clean polypropylene cages and fed with standard pellet diet and water ad libitum during the study. The animals were maintained under controlled temperature with $12 \mathrm{~h}$ dark cycle and $12 \mathrm{~h}$ light cycle. Twenty-four mice were divided into four groups [1-4] of six animals in each group for the study. Each group contains three male and three female mice.

\section{Preparation of plant extract}

Leaves of P. niruri were collected from local gardens of Coimbatore. Leaves were identified and authenticated by Botanist from Tamilnadu agriculture university, Coimbatore. Leaves are washed and shade dried at room temperature $\left(30^{\circ} \mathrm{C}\right)$ for 10 days. Leaves are powdered and stored. The aqueous extract was prepared by the Pharmacy department in Coimbatore Medical College. Based on body weight aqueous extract given to the mice oral by gavage tube (Table 1 ). 
Neuropharmacological profile (Irwin test)

The Irwin test is an observation test, which is commonly used to evaluate the effects of a new substance on behavior and physiological function [22]. The main aim of Irwin test is to determine potential toxicity and to select doses for specific therapeutic activity. The Irwin test can also be used in safety pharmacology, as an approach for detecting untoward effects of a new compound on general behavior and for evaluating its acute neurotoxicity [21].

Changes in neuropharmacological profile that is divided into behavioral, neurological, and autonomic profile were observed after administration of test drug in increasing doses.

\section{Neuropharmacological profile score}

Effects of the test substance were scored on a scale of 0-8. Base score was 4 for the normal signs or effects. Score below 4 indicates subnormal response and score above 4 are supernormal. The basal score for abnormal sign was 0 and maximal score was 8 .

\section{METHODOLOGY}

A total of 24 mice were divided into 4 groups of 6 each $(n=6,3$-male, 3 -female in each group). The mice were observed for $4 \mathrm{~h}$ after oral administration for various behavioral, neurological, and autonomic changes at $0,1,2,3,4 \mathrm{~h}$ according to Table 2. Each day two mice from different group was studied by Irwin's method.

\section{OBSERVATION AND RESULTS}

In Group I mice - there were no significant changes in behavioral profile, neurological profile, autonomic profile at $0,1,2,3,4 \mathrm{~h}$ for all six mice (Fig. 1).

Table 1: Drug, dose, and route of administration for different groups

\begin{tabular}{llll}
\hline Groups & Drug and dose & Mice & Route \\
\hline Group 1 & P. niruri $300 \mathrm{mg} / \mathrm{kg}$ & 6 & Oral \\
Group 2 & P. niruri $600 \mathrm{mg} / \mathrm{kg}$ & 6 & Oral \\
Group 3 & P. niruri $900 \mathrm{mg} / \mathrm{kg}$ & 6 & Oral \\
Group 4 & P. niruri $1200 \mathrm{mg} / \mathrm{kg}$ & 6 & Oral \\
\hline
\end{tabular}

P. niruri: Phyllanthus niruri

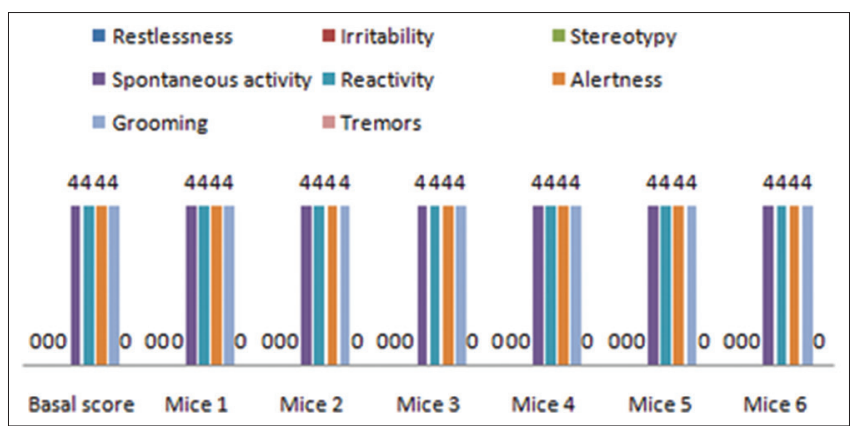

Fig. 1: Group I Phyllanthus niruri 300 mg/kg

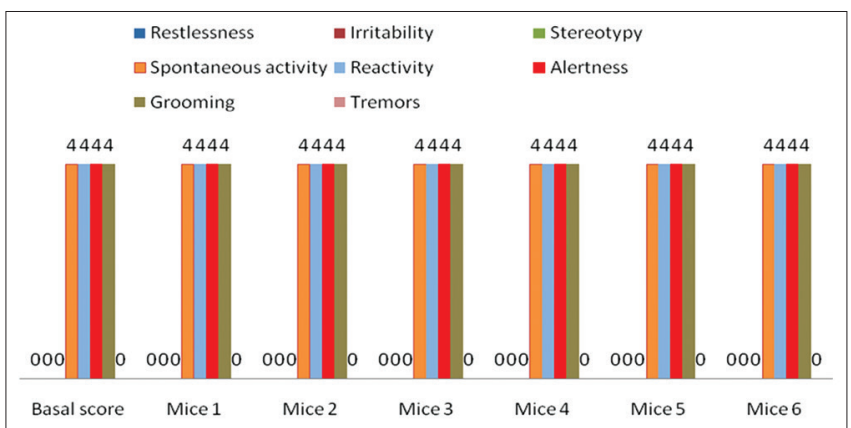

Fig. 2: Group II Phyllanthus niruri $600 \mathrm{mg} / \mathrm{kg}$
In Group II mice - there were no significant changes in behavioral profile, neurological profile, autonomic profile at $0,1,2,3,4 \mathrm{~h}$ for all six mice (Fig. 2)

In Group III mice - there was an observational change in behavioral profile at end of $4^{\text {th }} \mathrm{h}$ after $P$. niruri administration at dose of $900 \mathrm{mg} / \mathrm{kg}$ (Fig. 3).

Score of restlessness was 1 for 5 mice and 2 for 1 mouse, Irritability score was 1 for four mice and 2 for two mice, Stereotypy score was 1 for 4 mice.

Score for spontaneous activity, reactivity, alertness, grooming were 5 for six mice.

In Group IV mice - there was an observational change in behavioral profile at end of $4^{\text {th }} \mathrm{h}$ after $P$. niruri administration at dose of $1200 \mathrm{mg} / \mathrm{kg}$ (Fig. 4).

Score of restlessness was 2 for six mice, Irritability score was 2 for six mice, Stereotypy score was 1 for six mice. Score for spontaneous activity, reactivity, alertness, grooming were 6 for six mice.

There was also a change in neurological profile; score of tremors was 1 in all six mice at end of $4^{\text {th }} \mathrm{h}$.

\section{DISCUSSION}

P. niruri showed negligible actions at $300 \mathrm{mg} / \mathrm{kg}$ body weight and $600 \mathrm{mg} / \mathrm{kg}$ body weight. At $900 \mathrm{mg} / \mathrm{kg}$ and $1200 \mathrm{mg} / \mathrm{kg}$ P. niruri showed the following behavioral, neuronal changes.

P. niruri at dose of $900 \mathrm{mg} / \mathrm{kg}$ and $1200 \mathrm{mg} / \mathrm{kg}$ showed increased alertness, stereotypy, restlessness, irritability/aggressiveness in the behavioral profile. Its indicating that the drug has some CNS stimulant properties. At dose of $1200 \mathrm{mg} / \mathrm{kg}$ P. niruri showed mild tremors in neurological profile indicating it has some CNS excitation properties. No gross changes were observed in autonomic profile at given dose of P. niruri.

P. niruri has been widely studied for its hepatoprotective activity in in vitro andin vivo models. A previousstudy demonstrated that phyllanthus prevented memory impairment and possessed anticholinergic and

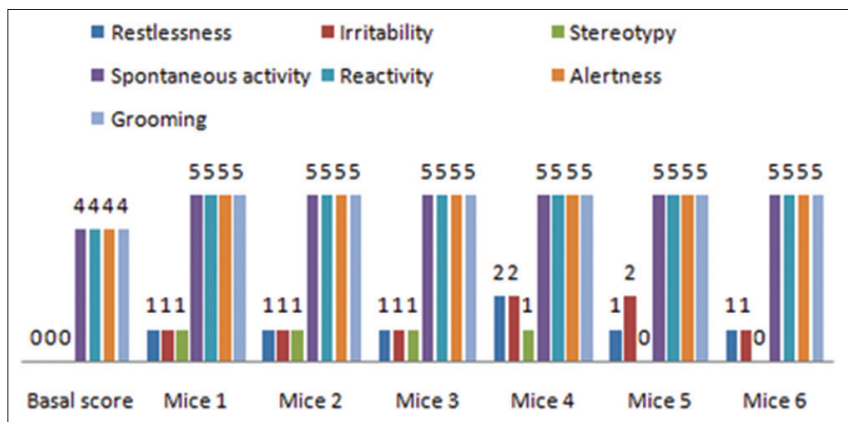

Fig. 3: Group III Phyllanthus niruri 900 mg/kg

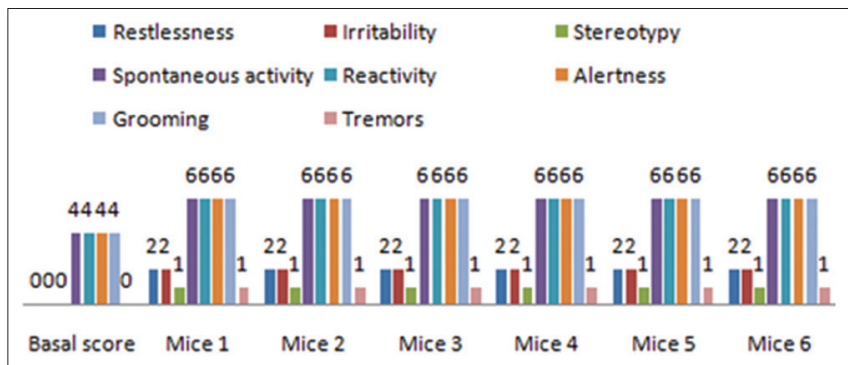

Fig. 4: Group IV Phyllanthus niruri 1200 mg/kg 
Table 2: Neuropharmacological profile of Phyllanthus niruri (Irwin's method)

\begin{tabular}{|c|c|c|c|c|c|c|c|c|c|c|c|c|c|c|c|c|c|c|c|c|c|c|}
\hline \multirow{2}{*}{ Time (h) } & & \multirow{2}{*}{ BS } & \multicolumn{5}{|c|}{$\begin{array}{l}\text { Group I phyllanthus } \\
300 \mathrm{mg} / \mathrm{kg}\end{array}$} & \multicolumn{5}{|c|}{$\begin{array}{l}\text { Group II phyllanthus } \\
600 \mathrm{mg} / \mathrm{kg}\end{array}$} & \multicolumn{5}{|c|}{$\begin{array}{l}\text { Group III phyllanthus } \\
900 \mathrm{mg} / \mathrm{kg}\end{array}$} & \multicolumn{5}{|c|}{$\begin{array}{l}\text { Group IV phyllanthus } \\
1200 \mathrm{mg} / \mathrm{kg}\end{array}$} \\
\hline & $\longrightarrow$ & & $\mathbf{0}$ & 1 & 2 & 3 & 4 & $\mathbf{0}$ & 1 & 2 & 3 & 4 & $\mathbf{0}$ & 1 & 2 & 3 & 4 & $\mathbf{0}$ & 1 & 2 & 3 & 4 \\
\hline \multirow[t]{2}{*}{ Behavioral } & Alertness & 4 & & & & & & & & & & & & & & & & & & & & \\
\hline & Visual placing & 4 & & & & & & & & & & & & & & & & & & & & \\
\hline \multirow[t]{2}{*}{ Awareness } & Passivity & 0 & & & & & & & & & & & & & & & & & & & & \\
\hline & Stereotypy & 0 & & & & & & & & & & & & & & & & & & & & \\
\hline \multirow[t]{5}{*}{ Mood } & Grooming & 4 & & & & & & & & & & & & & & & & & & & & \\
\hline & Vocalization & 0 & & & & & & & & & & & & & & & & & & & & \\
\hline & Restlessness & 0 & & & & & & & & & & & & & & & & & & & & \\
\hline & Aggression & 0 & & & & & & & & & & & & & & & & & & & & \\
\hline & Fearfulness & 0 & & & & & & & & & & & & & & & & & & & & \\
\hline \multirow[t]{4}{*}{ Motor activity } & Spontaneous activity & 4 & & & & & & & & & & & & & & & & & & & & \\
\hline & Reactivity & 4 & & & & & & & & & & & & & & & & & & & & \\
\hline & Touch response & 4 & & & & & & & & & & & & & & & & & & & & \\
\hline & Pain response & 4 & & & & & & & & & & & & & & & & & & & & \\
\hline \multirow{2}{*}{ Neurological } & Startle response & 0 & & & & & & & & & & & & & & & & & & & & \\
\hline & Straub tail & 0 & & & & & & & & & & & & & & & & & & & & \\
\hline CNS & Tremors & 0 & & & & & & & & & & & & & & & & & & & & \\
\hline \multirow{2}{*}{ Excitation } & Twitches & 0 & & & & & & & & & & & & & & & & & & & & \\
\hline & Convulsions & 0 & & & & & & & & & & & & & & & & & & & & \\
\hline \multirow[t]{2}{*}{ Posture } & Body posture & 4 & & & & & & & & & & & & & & & & & & & & \\
\hline & Limb position & 4 & & & & & & & & & & & & & & & & & & & & \\
\hline Motor in & Staggering gait & 0 & & & & & & & & & & & & & & & & & & & & \\
\hline \multirow{2}{*}{ coordination } & Abnormal gait & 0 & & & & & & & & & & & & & & & & & & & & \\
\hline & Righting reflex & 0 & & & & & & & & & & & & & & & & & & & & \\
\hline \multirow[t]{5}{*}{ Muscle tone } & Limb tone & 4 & & & & & & & & & & & & & & & & & & & & \\
\hline & Grip strength & 4 & & & & & & & & & & & & & & & & & & & & \\
\hline & Body sag & 0 & & & & & & & & & & & & & & & & & & & & \\
\hline & Body tone & 4 & & & & & & & & & & & & & & & & & & & & \\
\hline & Abnormal tone & 4 & & & & & & & & & & & & & & & & & & & & \\
\hline Reflexes & Pinna & 4 & & & & & & & & & & & & & & & & & & & & \\
\hline & Corneal & 4 & & & & & & & & & & & & & & & & & & & & \\
\hline & Ipsilateral flexor reflex & 4 & & & & & & & & & & & & & & & & & & & & \\
\hline Autonomic & Writhing & 0 & & & & & & & & & & & & & & & & & & & & \\
\hline & Pupil size & 4 & & & & & & & & & & & & & & & & & & & & \\
\hline & Palpebral opening & 4 & & & & & & & & & & & & & & & & & & & & \\
\hline & Exopthalmoses & 0 & & & & & & & & & & & & & & & & & & & & \\
\hline & Urination & 0 & & & & & & & & & & & & & & & & & & & & \\
\hline & Salivation & 0 & & & & & & & & & & & & & & & & & & & & \\
\hline & Piloerection & 0 & & & & & & & & & & & & & & & & & & & & \\
\hline & Hypothermia & 0 & & & & & & & & & & & & & & & & & & & & \\
\hline & Skin color & 4 & & & & & & & & & & & & & & & & & & & & \\
\hline & Heart rate & 4 & & & & & & & & & & & & & & & & & & & & \\
\hline Misc. & Respiratory rate & 4 & & & & & & & & & & & & & & & & & & & & \\
\hline & Lacrimation & 0 & & & & & & & & & & & & & & & & & & & & \\
\hline Dead & Number & 0 & & & & & & & & & & & & & & & & & & & & \\
\hline
\end{tabular}

BS: Basal score

anti-inflammatory properties [23]. These findings suggested that Phyllanthus is neuroactive and can alter the brain functions. It had been also found that Phyllanthus at doses of $100-500 \mathrm{mg} / \mathrm{kg}$ for 14 days revealed non-toxic effect with no abnormalities in normal behavior and physiology of rats [24]. However, to the best of our knowledge, no studies regarding neuropharmacological profile for acute toxicity study for $P$. niruri was done. Therefore, the present study sought to investigate neuropharmacological profile of $P$. niruri using Irwin's method.

During this study, no death occurred to mice after drug administration. Limitation of this study is it's an observational test, which may prone to bias.

\section{CONCLUSION}

From the results of experiment conducted, aqueous extract of $P$. niruri at dose of $300 \mathrm{mg} / \mathrm{kg}$ and $600 \mathrm{mg} / \mathrm{kg}$ has no changes in behavioral profile, neurological profile, and autonomic profile in Swiss albino mice. However, at dose of $900 \mathrm{mg} / \mathrm{kg}$ and $1200 \mathrm{mg} / \mathrm{kg}$ P. niruri showed changes in behavioral profile, neurological profile, showing it as CNS stimulant properties. Since it is an observational study further research should be done to explore CNS stimulant properties in various in vivo studies.

\section{CONFLICT OF INTEREST}

No conflict of interest to disclose.

\section{FUNDING}

Self funding.

\section{REFERENCES}

1. Singh T, Singh A, Kumar R, Singh JK. Acute toxicity study of Phyllanthus niruri and its effect on the cyto-architectural structure of nephrocytes in Swiss albino mice Mus-musculus. Pharmacogn J 2016;8:77-88

2. Haque T, Muhsin MD, Akhter T, Haq ME, Begum R, Chowdhury SF. Antimicrobial and analgesic activity of leaf extracts of Phyllanthus reticulatus Poir. (Family- Euphorbiaceae). Jahangirnagar Univ J Biol Sci 2016;5:81-5. 
3. Mao X, Wu LF, Guo HL, Chen WJ, Cui YP, Qi Q, et al. The genus Phyllanthus: An ethnopharmacological, phytochemical, and pharmacological review. Evid Based Complement Altern Med 2016;2016:7584952.

4. Oudhia P. Bhuiaonla (Phyllanthus niruri): A Useful Medicinal Weed. Available from: https://www.hort.purdue.edu/newcrop/cropfactsheets/ phyllanthus.html.

5. Kumar A, Rana AK, Singh A, Singh A. Effect of methanolic extract of Phyllanthus niruri on leptin level in animal model of diabetes mellitus. Biomed Pharmacol J 2019;12:57-63.

6. Janghel V, Patel P, Chandel SS. Plants used for the treatment of icterus (jaundice) in Central India: A review. Ann Hepatol 2019;18:658-72.

7. Mukherjee M, Gupta S. Evaluation of acute toxicity and anti-asthmatic activity of Phyllanthus niruri L. leaves extracts. Asian J Pharm Pharmacol 2018:4:615-9.

8. Porto CR, Soares LA, Souza TP, Petrovick PR, Lyra IL, Araújo Júnior RF, et al. Anti-inflammatory and antinociceptive activities of Phyllanthus niruri spray-dried standardized extract. Rev Bras Farmacogn 2013;23:138-44.

9. Tjandrawinata R, Susanto L, Nofiarny D. The use of Phyllanthus niruri $\mathrm{L}$. as an immunomodulator for the treatment of infectious diseases in clinical settings. Asian Pac J Trop Dis 2017;7:132-40.

10. Njoroge AD, Anyango B, Dossaji SF. Screening of Phyllanthus species for antimicrobial properties. Chem Sci J 2012;2012:CSJ-56.

11. Sheila Maregesi M, Kauke B, Kagashe G, Kaali R. Traditional eye medicines in Tanzania: Products, health risk awareness and safety evaluation. Herb Med 2016;2:1.

12. Mollik AH, Islam T, Khatun A, Hossan S, Nasrin D, Jahan R, et al. Medicinal plants used against syphilis and gonorrhea by traditional medicinal practitioners of Bangladesh. Planta Med 2009;75:PH40.

13. Pasha F, Irfan S. A study on antimicrobial properties of Phyllanthus niruri and Ocimum sanctum. Biomed Pharmacol J 2015;4:297-9.

14. Boim MA, Heilberg IP, Schor N. Phyllanthus niruri as a promising alternative treatment for nephrolithiasis. Int Braz J Urol 2010;36:657-64 .

15. Kaur B, Kaur N, Gautam V. Evaluation of anti-helicobacter pylori (DSMZ 10242) activity and qualitative analysis of quercetin by HPLC in Phyllanthus niruri linn. World J Pharm Pharm Sci 2016;6:1691-706.

16. Patel JR, Tripathi P, Sharma V, Chauhan NS, Dixit VK. Phyllanthus amarus: Ethnomedicinal uses, phytochemistry and pharmacology: A review. J Ethnopharmacol 2011;138:286-313.

17. Kamruzzaman HM, Hoq MO. A review on ethnomedicinal, phytochemical and pharmacological properties of Phyllanthus niruri. J Med Plants Stud 2016;4:173-80.

18. Bagalkotkar G, Sagineedu S, Saad M, Stanslas J. Phytochemicals from Phyllanthus niruri Linn. and their pharmacological properties: A review. J Pharm Pharmacol 2007;58:1559-70.

19. Nijveldt RJ, van Nood E, van Hoorn DE, Boelens PG, van Norren K, van Leeuwen PA. Flavonoids: A review of probable mechanisms of action and potential applications. Am J Clin Nutr 2001;74:418-25.

20. Mathiasen JR, Moser VC. The Irwin test and Functional Observational Battery (FOB) for assessing the effects of compounds on behavior, physiology, and safety pharmacology in rodents. Curr Protoc Pharmacol 2018:83:e43

21. Roux S, Sablé E, Porsolt RD. Primary observation (Irwin) test in rodents for assessing acute toxicity of a test agent and its effects on behavior and physiological function. Curr Protoc Pharmacol 2005; Chapter 10:Unit 10.10 .

22. Irwin S. Comprehensive observational assessment: Ia. A systematic, quantitative procedure for assessing the behavioral and physiologic state of the mouse. Psychopharmacologia 1968;13:222-57.

23. Joshi H, Parle M. Evaluation of the antiamnesic effects of Phyllanthus amarus in mice. Rev Colomb Méd 2007;38:132-9.

24. Ilangkovan M, Jantan I, Mesaik MA, Bukhari SNA. Immunosuppressive effects of the standardized extract of Phyllanthus amarus on cellular immune responses in Wistar-Kyoto rats. Drug Des Devel Ther $2015 ; 9: 4917-30$ 